\title{
The Trial of David Hicks and the Law on the Use of Force
}

\section{Introduction}

David Hicks is an Australian citizen in the custody of the government of the United States of America at Guantánamo Bay, Cuba. He was alleged to have served with the Taliban and al-Qaeda in Afghanistan. This led to his detention for more than five years as an 'unlawful combatant'. This category, it is claimed, is outside the normal protections of United States Constitutional due process and criminal law, and outside relevant provisions of international law especially the Geneva Conventions.

Hicks' initial charges alleged conspiracy, attempted murder by an unprivileged belligerent and aiding the enemy. His trial before a United States military commission was due to begin in November 2005. These proceedings were cancelled following the Supreme Court ruling in Hamdan $v$ Rumsfeld ${ }^{1}$ that declared the military commission process unconstitutional and illegal.

The response of the United States Government was then to pass the Military Commissions Act of $2006^{2}$ and press new charges. The new charges encompassed providing material support for terrorism and attempted murder in violation of the law of war. ${ }^{3}$ On 26 March 2007 Hicks was convicted on his own guilty pleas for the former, sentenced to seven years imprisonment, all but nine months suspended and most of it to be served in an Australian prison. ${ }^{4}$ This note focuses on the legality (as opposed to the expediency or propriety) of the process. The underlying reasoning is unaffected by David Hicks having entered a guilty plea, the validity of which is highly debatable.

\section{Distinctions and their Implications}

The so-called 'war against terror' raises numerous issues fraught with distinctions having far-reaching implications (Megret 2002:361-399, esp 377). For example, the distinctions between war (a state of armed conflict) and peace (the absence of armed conflict) or between combatants (those who engage in armed hostilities) and non-combatants (those who do not, or no longer, engage in armed hostilities), extra-territorial domestic criminal law enforcement and armed conflict, etc are all consciously effaced to the detriment of David Hicks.

The legal basis for his trial is partly found in the case of Ex parte Quirin. Here the Supreme Court of the United States upheld the jurisdiction of a United States military tribunal over unlawful enemy combatants and approved their being sentenced to death. The

1 On 29 June 2006, the court issued a 5-3 decision holding that it (contrary to the Federal Government's arguments) had jurisdiction, that the Federal Government did not have authority to set up these particular military commissions, and that the military commissions were illegal under both the Uniform Code of Military Justice and the Geneva Conventions 126 SCt 2749 (2006).

2 Pub L No 109-366, 120 Stat 2600 (17 October 2006).

3 <www.defenselink.mil/news/d2007Hicks\%20-\%20Notification\%20of\%20Sworn\%20Charges.pdf> accessed 21 February 2007.

4 <www.theaustralian.news.com.au/story/0,20867,21454470-601,00.html> and <www.news.com.au/story/0,23599,21478966-2,00.html> both accessed 31 March 2007. 
court stated that: 'Lawful combatants are subject to capture and detention as prisoners of war by opposing military forces. Unlawful combatants are likewise subject to capture and detention, but in addition they are subject to trial and punishment by military tribunals for acts which render their belligerency unlawful' (Ex parte Quirin at 31).

This decision however only covers conduct of hostilities. It in no way refers to the reasons for engaging in hostilities or the capacity to engage in armed conflict and is therefore (as explained below) of limited utility in Hicks' specific circumstances.

To start with the term itself, the 'war against terror' is a misnomer in that it is neither a war nor is it even against terror. ${ }^{5}$ To be sure, there are wars against the States of Afghanistan and Iraq that can be located in both space and time. But the noun 'terror' essentially references a tactic of political violence unrestricted in actors, time and space. The point is that the figurative rubric of a war against terror makes all these literal wars actually possible in the political and physical realms (Megret 2002:esp377). However, Realpolitik doesn't make good law. Neither does it make bad law. It is simply not the law.

Crucially, international law distinguishes between why and how one fights. Reasons permissible to fight are found in the law on the use of force (principally the United Nations Charter and customary international law) while how one fights is governed by the law of armed conflict/international humanitarian law (codified in the Hague and Geneva Conventions). So, for example, deliberately targeting civilians is a breach of the latter while taking up arms in self-defence is in keeping with the former. In the 'war against terror' this fundamental distinction is finessed for political capital. The cause for which the terrorists fight is discredited by the methods that they use (deliberately targeting civilians) while the methods that the authorities use (re-defining torture, domestic surveillance, invasion of countries, etc) are absolved by the cause (security) for which the authorities fight.

Because the law has to be manipulated in one way or another to justify this logic, issues of abuse of power by illegitimate use of legal processes arise. Ousting the jurisdiction of non-military courts and unilaterally suspending the operation of law are by now familiar tactics.

\section{Lack of Due Process and Abuse of Process}

The legality of the entire process is thus open to question. John Howard, the Australian Prime Minister, stated that it was well within his power to free Hicks at any time presumably even without trial. ${ }^{6}$ He, instead, elected to ask the United States to speed up Hicks' proposed trial. ${ }^{7}$ This was an unwitting but nonetheless unmistakeable admission of the political calculations involved in the affair, resulting in a concocted semantic legal vacuum currently filled by political power and discretion without recourse to objective adjudication.

In contrast to Australia, the British demanded and got their citizens repatriated home from Guantánamo Bay. In fact, David Hicks sought and obtained British citizenship to avail

5 The Director of Public Prosecutions in England and Wales, Sir Ken Macdonald had occasion to say 'We need to be very clear about this. On the streets of London, there is no such thing as a "war on terror", just as there can be no such thing as a "war on drugs"': <http://politics.guardian.co.uk/terrorism/story/ 0,,1997247,00.html> accessed 21 February 2007.

6 <www.smh.com.au/news/national/pm-i-could-free-hicks--but-wont/2007/02/06/1170524096341.html> accessed 2 February 2007

7 <http://abc.net.au/news/newsitems/200611/s1785856.htm>. 
himself of similar protections only to have the citizenship duly granted and promptly stripped in a matter of hours to deny him the remedy. ${ }^{8}$

Why has this happened? David Hicks has his freedom taken away from him not for what he did per se but what he represents. He is seen (rightly or wrongly) as representing persons willing to take up arms against the United States and possibly its allies as well. ${ }^{9}$ The wisdom and patriotic filial feeling of such a decision aside, he has taken up an aggressive, highly threatening and deeply unpopular political decision. But is this a crime in itself? If it is, then it has to be a breach of the international law on the use of force, which the United States could then enforce on behalf of the international community by criminal sanctions.

\section{De-Internationalising and Domesticating the Law on the Use of Force}

While the United States excludes its own use of force from any legal purview, whether domestic or international, it actively criminalises other state's and even individuals' resort to armed force against itself. Such use of force is then characterised as a breach of United States domestic criminal law rather than international criminal law.

At the Rome conference for the establishment of the International Criminal Court, the United States opposed development of the law on the use of force by international codification of a crime of aggression. ${ }^{10}$ Notwithstanding, the Military Commissions Act of 2006 in s948 defines lawful enemy combatants as members of regular forces, militia, or volunteer corps of a state, or members of a regular armed force professing allegiance to a government not recognised by the United States, engaged in hostilities against it.

This drafting explicitly distinguishes lawful combatants from unlawful enemy combatants who are persons that include members of the Taliban and al Qaeda. The legal consequence of such classification is that the Taliban and al Qaeda affiliates are, by definition, unlawful enemy combatants for the mere fact of taking part in hostilities against the United States.

Here the United States conflates the distinction between recognising a government and recognising a state. It did not recognise the Taliban as the lawful government of Afghanistan even when the Taliban was in control of 70 per cent of the country's territory but recognised the Northern Alliance instead that controlled 30 per cent. Therefore, it withheld from members of the Taliban the privilege of being lawful combatants. However, Afghanistan is and was a state party to the Geneva Conventions. This has not changed whether or not its government was recognised. This is likewise for the al Qaeda members captured in Afghanistan engaging in hostilities on behalf of the Taliban government. It is

8 <www.smh.com.au/news/world/law-strips-hicks-of-uk-citizenship-in-hours/2006/08/19/ 1155408075077.html> accessed 21 February 2007.

9 <www.defenselink.mil/news/d2007Hicks\%20-\%20Notification\%20of\%20Sworn\%20Charges.pdf> accessed 21 February 2007.

10 Mr Bill Richardson, for the US: 'The Court must have a clear, precise and well-established understanding of what conduct constituted a crime. At the same time, acts not clearly criminalized under international law should be excluded from the definition. It was, therefore, premature to attempt to define a crime of aggression in terms of individual criminal responsibility. Vague formulas that left the Court to decide on the fundamental parameters of crimes should be avoided.' See United Nations Document United Nations Diplomatic Conference of Plenipotentiaries on the Establishment of an International Criminal Court Rome, 15 June - 17 July 1998 Official Records Volume II Summary records of the Plenary Meetings and of the Meetings of the Committee of the Whole Doc No A/CONF 183/13 (Vol II) p 95 at para 61. 
not possible to make war against a non-state actor outside your territory without invitation from the state it is operating in (or from) unless you declare war on that state and conduct hostilities on that basis. Therefore the criminalising of unlawful resort to political violence is laudable and to be supported by reference to all states in international law and not just a single state through its domestic law.

\section{Conclusion}

It is said that David Hicks was an unlawful combatant, which deprives him of the protections of the law applicable in both war and peace but without waiving his own obligation to obey them. He is in a double bind, having all the obligations under both United States domestic criminal law and international law but none of the entitlements under the same laws, while his accusers have all of the entitlements (to prosecute breaches of domestic criminal law and wars on other countries) but none of the obligations (to respect human rights and the international rule of law). ${ }^{11}$

David Hicks and the rule of law deserve better respect. He deserves to be treated by a legal process that is untangled from the politics of expediency.

\section{Edwin Bikundo}

PhD Candidate, University of Sydney

\section{Case}

Ex parte Quirin 317 US 1 (1942).

\section{Reference}

Megret, F (2002) ““War”? Legal Semantics and the Move to Violence', European Journal of International Law, vol 13, no 2, p 361.

11 By analogy, what if the Iraqis, prior to the Second Gulf War, had declared they did not recognise the United States Republican administration due to the controversial 2000 presidential election and that therefore all American soldiers in Iraq were unlawful combatants and liable for prosecution under the death penalty. 